\title{
Temperature effects on thirst: Cutaneous or oral receptors?
}

\author{
HARRY J. CARLISLE \\ University of California, Santa Barbara, California 93106
}

\begin{abstract}
Water intake of rats was not greatly different as a function of the ambient temperature in which the water was consumed provided that the temperature of the water was maintained at $25^{\circ} \mathrm{C}$. If water temperature was allowed to follow ambient temperature, then less water was consumed in cool environments. Thirst is modulated by receptors in or around the mouth and not in the skin.
\end{abstract}

It is well-known that water intake varies directly with ambient temperature (Budgell, 1970; Hamilton, 1963), presumably as a consequence of afferent information from temperature receptors in the skin (Fitzsimons, 1972). There is now considerable evidence to show that water intake also varies directly with water temperature (Gold, Kapatos, Prowse, Quackenbush, \& Oxford, 1973; Gold \& Prowse, 1974; Kapatos \& Gold, 1972). Unless independently controlled, the temperature of drinking water tends to follow variations in ambient temperature. Could the effect on water intake attributed to ambient temperature be due to the temperature of drinking water? If so, the appropriate receptor system mediating the modulation of water intake would be located in or around the mouth and not in the skin. This notion was tested in three experiments in which water temperature was controlled independently of ambient temperature.

\section{METHOD}

\section{Animals and Apparatus}

Six adult female rats of the Sprague-Dawley strain with body weights of $211-263 \mathrm{~g}$ were kept in a colony room maintained at $23 \pm 2{ }^{\circ} \mathrm{C}$ and given access to water for $20 \mathrm{~min}$ each day in a Model 1316 Lehigh Valley test apparatus located in a $3 \times 2.5$ $\times 2.5 \mathrm{~m}$ temperature-controlled room. Purina Chow pellets were available ad lib except during each daily drinking test. Water temperature was controlled by circulating water from a constanttemperature bath to copper tubing wrapped around the metal spout of a drinking tube, the aperture of which was $4 \mathrm{~mm}$ outside a $1.8 \times 3.2 \mathrm{~cm}$ slot in the wall of the animal enclosure. The maximal variation in the temperature of drinking water during a test, as measured by a thermistor inside the drinking tube near the tip, was $\pm 1^{\circ} \mathrm{C}$. Water intake was determined by reading the level of a calibrated buret to the nearest $0.1 \mathrm{ml}$. Pre- and posttest rectal temperature was measured with a Yellow Springs Instrument Co. Model 46 Telethermometer and small-animal probe inserted $6 \mathrm{~cm}$. Two weeks of daily tests were given with neutral $\left(25^{\circ} \mathrm{C}\right)$ water and ambient temperatures to assure stable intakes before the first experiment commenced.

Procedure

In the first experiment, the animals were given daily access to water of $25^{\circ} \mathrm{C}$ for $20 \mathrm{~min}$ at ambient temperatures which varied between $5^{\circ}$ and $40^{\circ} \mathrm{C}$ in $5^{\circ} \mathrm{C}$ steps. One temperature was in effect each day. An ascending series of temperatures was given first, followed by a descending series so that each subject received two tests at each temperature. The second experiment provided water that was either controlled at $25^{\circ} \mathrm{C}$ or free to vary with ambient temperatures of $5^{\circ}, 15^{\circ}, 25^{\circ}$, or $35^{\circ} \mathrm{C}$. Random presentations of the various combinations of ambient and water temperature were given until two exposures to each condition were obtained. A washout day was interposed in the testing sequence following days in which average intake was reduced by more than $1 \mathrm{ml}$ from intakes at $25^{\circ} \mathrm{C}$. The third experiment examined the influence of ambient temperature when the animals were exposed to that temperature in a $21 \times 28 \times 60 \mathrm{~cm}$ high wooden box on wood shavings for $1 \mathrm{~h}$ prior to the 20-min drinking test. Water temperature was either controlled at $25^{\circ} \mathrm{C}$ or free to vary with ambient temperature of $5^{\circ}, 15^{\circ}, 25^{\circ}$, and $35^{\circ} \mathrm{C}$. Two exposures to each combination of water and ambient temperature were given in a random order.

\section{RESULTS}

Mean water intake at $25^{\circ} \mathrm{C}$ was $14.3 \mathrm{ml}$, and average intakes did not vary more than $1 \mathrm{ml}$ from this value as a function of ambient temperature when water temperature was held constant at $25^{\circ} \mathrm{C}$ (Figure 1). Water intake at $35^{\circ} \mathrm{C}$ was significantly greater than at $10^{\circ} \mathrm{C}$ (t test, $\mathrm{p}<.05$ ), and intake at $40^{\circ} \mathrm{C}$ was greater than at $5^{\circ} \mathrm{C}(\mathrm{p}<.05)$ and $10^{\circ} \mathrm{C}$ $(\mathrm{p}<.01)$. No other comparisons were significant. Thus, some extreme ambient temperatures differed from one another but not from neutral $\left(25^{\circ} \mathrm{C}\right)$. A linear regression line fit to the data of Figure 1 yielded a slope of $0.03 \mathrm{ml} /{ }^{\circ} \mathrm{C}$ with a correlation coefficient for goodness of fit of 0.76 .

In Experiment 2, significantly less water was taken when water temperature was allowed to follow ambient temperatures of $5^{\circ}$ and $15^{\circ} \mathrm{C}(\mathrm{t}$ tests, $\mathrm{p}<.01$ ) but not $25^{\circ}$ or $35^{\circ} \mathrm{C}$. As in the first experiment, ambient temperature alone made little difference when water temperature was maintained at $25^{\circ} \mathrm{C}$ (Figure 2). In Experiment 3, less water was consumed when water temperature was not controlled than when it was maintained at $25^{\circ} \mathrm{C}$ in the cool 


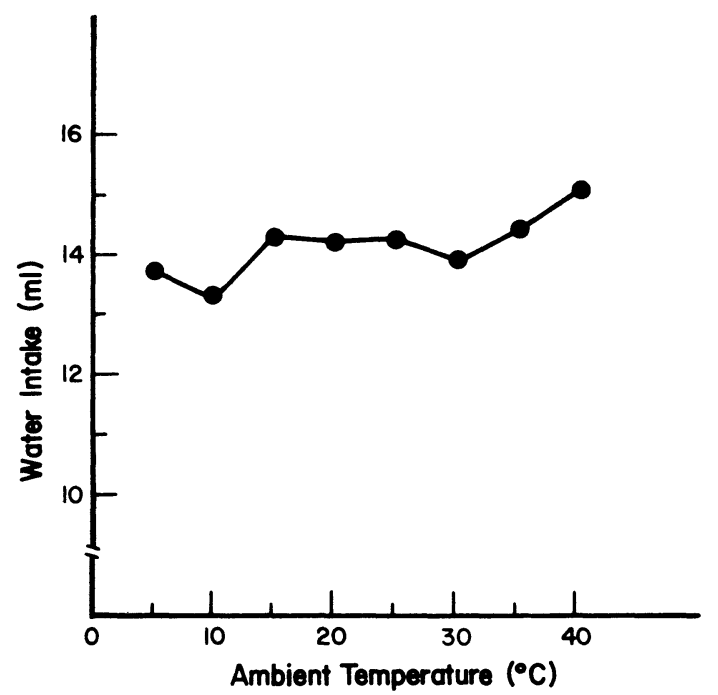

Figure 1. Mean water intake when ambient temperature was varied with water temperature held constant at $25^{\circ} \mathrm{C}$.

ambient temperatures. In addition, comparing intakes at $5^{\circ} \mathrm{C}$ in Experiments 2 and 3, less water was taken when the animals were exposed for $1 \mathrm{~h}$ both with water temperature controlled at $25^{\circ} \mathrm{C}(\mathrm{p}<.01)$ and uncontrolled $(p<.05)$. Thus, ambient temperature alone influenced water intake only at the $5^{\circ} \mathrm{C}$ condition and then only when the animals were exposed to that temperature for an hour.

Rectal temperature varied with ambient temperature, but, like ambient temperature itself, did not appear to influence water intake independently of water temperature. For example, posttest rectal temperature was significantly elevated at $30^{\circ}, 35^{\circ}$, and $40^{\circ} \mathrm{C}$ compared to $25^{\circ} \mathrm{C}$ in Experiment 1 , but water intake did not so vary. In Experiment 2, water intakes differed but rectal temperatures were the same when water temperature was either controlled or uncontrolled at $5^{\circ} \mathrm{C}$. In Experiment 3, after 1-h exposure to $5^{\circ}, 15^{\circ}, 25^{\circ}$, or $35^{\circ} \mathrm{C}$, mean rectal temperatures were $38.6^{\circ}, 38.9^{\circ}, 39.3^{\circ}$, and $40.1^{\circ} \mathrm{C}$, respectively. Water intake was not significantly different when rectal temperature differences were large, as at $25^{\circ}$ and $35^{\circ} \mathrm{C}$. Conversely, rectal temperature differences were minimal (less than $0.2^{\circ} \mathrm{C}$ ) when water intake differences were large for the four conditions at $5^{\circ} \mathrm{C}$ shown in Figure 2 . In general, water intake was influenced by water temperature and not body temperature.

\section{DISCUSSION}

The main outcome of this study is that when water temperature is controlled independently of ambient temperature, then ambient temperature alone has little influence on water intake except when (a) ex- treme ambient temperature differences are compared, or (b) the animal is exposed to that temperature for some time. Experiment 1 showed there was little variation in water intake when water temperature was held constant and ambient temperature was varied over a range between $5^{\circ}$ and $40^{\circ} \mathrm{C}$. The slope of the line relating water temperature to ambient temperature was $0.03 \mathrm{ml} /{ }^{\circ} \mathrm{C}$. In contrast, when water temperature was varied at a constant ambient temperature, the slope of the line was approximately $0.22 \mathrm{ml} /{ }^{\circ} \mathrm{C}$ [calculated from the data of Kapatos and Gold (1972) for water temperatures between $12^{\circ}$ and $36^{\circ} \mathrm{C}$ ]. Water temperature thus has a seven times greater influence on water intake than does ambient temperature. Similarly, Experiment 2 showed that water intake decreased when the temperature of the water was not controlled in cool ambient temperatures of $5^{\circ}$ and $15^{\circ} \mathrm{C}$ compared to either a neutral $\left(25^{\circ} \mathrm{C}\right)$ ambient temperature or to a controlled water temperature $\left(25^{\circ} \mathrm{C}\right)$ in the cool environments. Experiment 3 showed that ambient temperature does have an effect independently of

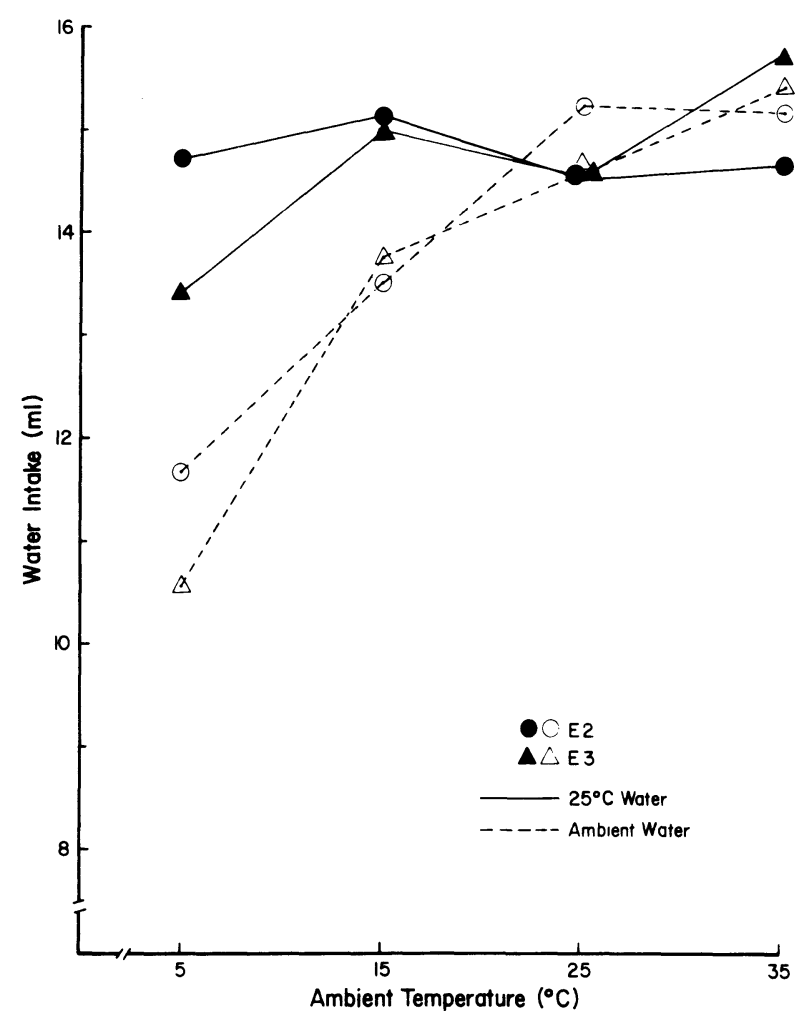

Figure 2. Water intake as a function of ambient temperature when water temperature was $25^{\circ} \mathrm{C}$ (filled symbols) or uncontrolled (open symbols) in Experiments 2 (circles) and 3 (triangles). When uncontrolled, the temperature of the drinking water averaged $3.5^{\circ}, 13.5^{\circ}, 23.5^{\circ}$, and $28.5^{\circ} \mathrm{C}$ at ambient temperatures of $5^{\circ}$, $15^{\circ}, 25^{\circ}$, and $35^{\circ} \mathrm{C}$, respectively. 
water temperature, but only at the cold $\left(5^{\circ} \mathrm{C}\right)$ condition, and only when the animal is exposed to that temperature for $1 \mathrm{~h}$.

These results demonstrate that cool water reduces water intake during brief, 20-min drinking tests while ambient temperature has little influence except in a cold $\left(5^{\circ} \mathrm{C}\right)$ environment and then only with prior cold exposure. Perhaps the latter effect is related to the cold-induced diuresis and voluntary dehydration observed in chronically cold-exposed animals (Fregly, 1967; Fregly \& Waters, 1966). Water temperature, unlike ambient temperature, appears to have an immediate satiating effect on thirst which suggests the involvement of an orolingual receptor mechanism (Weijnen, 1975). An alternative explanation for the satiating effect of cold water, namely its slow rate of clearance from the stomach (Deaux, 1973), would not seem to be applicable when water suppression is immediate. Cold water reduces water intake during the short (less than $30 \mathrm{sec}$ ) bursts of drinking that occur on intermittent schedules of food reinforcement (Carlisle \& Laudenslager, 1976). Similarly, the stomach clearance hypothesis does not explain why thirsty animals lick a cold, dry tube (Mendelson \& Chillag, 1970) or air (Hendry \& Rasche, 1961). These observations are consistent with the view that orolingual cooling alone has a satiating effect on thirst. Although postingestive mechanisms cannot be ruled out at this time, the receptors mediating the temperature dependency of thirst are probably located primarily in or around the mouth, certainly not in the skin.

\section{REFERENCES}

Budgell, P. The effect of changes in ambient temperature on water intake and evaporative water loss. Psychonomic Science, 1970, 20, 275-276.

Carlisle, H. J., \& Laudenslager, M. L. Separation of water and ambient temperature effects on polydipsia. Physiology and Behavior, 1976, 16, 121-124.

DEAUX, E. Thirst satiation and the temperature of ingested water. Science, 1973, 181, 1166-1167.

Fitzsimons, J. T. Thirst. Physiological Reviews, 1972, 52, 468-561. Fregly, M. J. Effect of exposure to cold on evaporative loss from rats. American Journal of Physiology, 1967, 213, 1003-1008.

FREGLY, M. J., \& WATERS, I. W. Water intake of rats immediately after exposure to a cold environment. Canadian Journal of Physology and Pharmacology, 1966, 44, 651-662.

Gold, R. M., \& Prowse, J. Water temperature preference shifts during hydration. Physiology and Behavior, 1974, 13, 291-296.

Gold, R. M., Kapatos, G., Prowse, J., Quackenbush, P. M., \& OXForD, T. W. Role of water temperature in the regulation of water intake. Journal of Comparative and Physiological Psychology, 1973, 85, 52-63.

HAMILTON, C. L. Interactions of food intake and temperature regulation in the rat. Journal of Comparative and Physiological Psychology, 1963, 56, 476-488.

HeNDRY, D. P., \& RASChe, R. H. Analysis of a new nonnutritive positive reinforcer based on thirst. Journal of Comparative and Physiological Psychology, 1961, 54, 477-483.

Kapatos, G., \& Gold, R. M. Tongue cooling during drinking: A regulator of water intake in rats. Science, 1972, 176, 685-686.

Mendelson, J., \& Chillag, D. Tongue cooling: A new reward for thirsty rodents. Science, 1970, 170, 1418-1421.

WeIJNEN, J. A. W. M. Lingual stimulation and water intake. In G. Peters, J. T. Fitzsimons, \& L. Peters-Haefeli (Eds.), Control mechanisms of drinking. Berlin: Springer-Verlag, 1975. Pp. 9-13.

(Received for publication January 21, 1977; accepted February 4, 1977.) 